Research Article

\title{
Risk Assessment of Trace Element Contamination in Drinking Water and Agricultural Soil: A Study in Selected Chronic Kidney Disease of Unknown Etiology (CKDu) Endemic Areas in Sri Lanka
}

\author{
W. P. R. T. Perera ${ }^{D},{ }^{1}$ M. D. N. R. Dayananda $\left(D,{ }^{1}\right.$ D. M. U. C. Dissanayake, \\ R. A. S. D. Rathnasekara, ${ }^{1}$ W. S. M. Botheju, ${ }^{1}$ J. A. Liyanage $\left(\mathbb{D},{ }^{1}\right.$ S. K. Weragoda, ${ }^{2}$ \\ and K. A. M. Kularathne ${ }^{2}$ \\ ${ }^{1}$ Department of Chemistry, Faculty of Science, University of Kelaniya, Kelaniya, Sri Lanka \\ ${ }^{2}$ National Water Supply and Drainage Board, Katugastota 20800, Sri Lanka \\ Correspondence should be addressed to W. P. R. T. Perera; 2017_perera@kln.ac.lk
}

Received 2 December 2020; Revised 14 January 2021; Accepted 20 January 2021; Published 29 January 2021

Academic Editor: Zenilda Cardeal

Copyright (c) 2021 W. P. R. T. Perera et al. This is an open access article distributed under the Creative Commons Attribution License, which permits unrestricted use, distribution, and reproduction in any medium, provided the original work is properly cited.

\begin{abstract}
Unexplained or unclear etiology of chronic kidney disease $(\mathrm{CKDu})$ has been reported in Sri Lanka's North Central Province (NCP) for more than two decades. Meanwhile, high exposure to heavy metals/metalloids and their accumulation are recognized as the origin of many acute and chronic diseases in certain vulnerable human tissues including kidneys. This study evaluates the contamination status of heavy metals/metalloids of the drinking water and agricultural soil in two CKDu endemic areas compared with a reference area in Sri Lanka based on common indexes and attribute of the commonly used fertilizers evaluated to identify the basic sources of toxic metals in the agricultural soil. Mean concentrations of heavy metals/metalloids such as $\mathrm{Mn}, \mathrm{Co}, \mathrm{As}, \mathrm{Cd}$, $\mathrm{Pb}, \mathrm{Cu}, \mathrm{Zn}$, and $\mathrm{Fe}$ in drinking water of $\mathrm{CKDu}$ endemic areas were far below Sri Lankan water quality standards (permissible limits). In addition, all sampling locations dropped below the medium range of the heavy metal pollution index of water (HPI 15-40). Geoaccumulation indexes $\left(I_{\text {geo }}\right)$ of soil reveal that paddy soil in CKDu endemic areas is being moderately polluted with toxic metals/metalloids such as $\mathrm{As}, \mathrm{Pb}, \mathrm{Cu}, \mathrm{Ni}, \mathrm{Cr}, \mathrm{Zn}$, and $\mathrm{Cd}$. On the other hand, the application of fertilizers, which contained a high dose of toxic metals, could be the driving force for agricultural soil pollution, and limitless application of low-quality fertilizer would lead to more soil contamination with heavy metals. Hence, hazardous metals can be incorporated into the food chains via contaminated paddy soil.
\end{abstract}

\section{Introduction}

Chronic kidney disease unknown etiology $(\mathrm{CKDu})$ was first discovered in Sri Lanka in the mid-1990s, mainly found among farmers in Sri Lanka's North Central Province (NCP); since then, the disease has spread dramatically over a span of two decades, including other agricultural areas of the country such as the North, North West, Eastern, Uva, and Central Provinces [1-3]. Chronic kidney disease (CKD) is a noncommunicable disease that is related to risk factors such as diabetes or hypertension, past snakebites, and urinary tract infections. The aforementioned risk factors of CKD or family history of kidney failures are not responsible for the occurrence of chronic kidney disease of unknown etiology [4]. Geographic "hotspots" of CKDu have emerged in a number of countries, including El Salvador, Guatemala, Mexico, Nicaragua, Bulgaria, Croatia, Serbia, India, and Sri Lanka [5], and it is prevalent among agricultural workers with several symptoms including fatigue, panting, lack of appetite, nausea, and anemia [6]. The studies of $\mathrm{CKDu}$ in Sri Lanka are significant because of the increasing number of Sri Lankans who are suffering from CKDu since the 1990s, e.g., more than 50,000 patients diagnosed with late-stage kidney disease, and the majority of these patients are reported from the North Central Province (NCP) [7]. Hence, potentially 
causative agents for the prevalence of kidney disease must be present in drinking water and soils of the endemic areas in sufficient quantities [4].

Although some of the heavy metals are known to be enhancing human body functions, the same heavy metals above their critical limits and some others are toxic for human beings [8]. There are so many major pathways to contamination of groundwater and soil with nephrotoxic contaminants such as heavy metals and counterions with the chemical applications due to the intense agriculture. Those toxicants exist as clusters in the environment [9]. And exposure to those may be linked to conditions such as neurotoxicity in human kidneys. Exposure to metals such as As, $\mathrm{Cd}, \mathrm{Hg}, \mathrm{Cr}, \mathrm{Ni}, \mathrm{Mn}$, and $\mathrm{Fe}$ present in the drinking water significantly collaborated with the functional and structural integrity of kidneys $[10,11]$. According to the toxicological studies on nephrotoxicity, exposure to cation species of $\mathrm{Pb}$, As, and Cd can be associated with renal tubular necrosis, and exposure to heavy metals such as $\mathrm{Pb}, \mathrm{Hg}$, and $\mathrm{Cd}$ is directly associated with the collapse of glomeruli [12]. Kidney dysfunction was correlated with high creatinine level which results from exposure to a low dose of $\mathrm{Pb}, \mathrm{As}$, and $\mathrm{Cd}$. High creatinine levels indicate a weak glomerular filtration process which means reduced ability to excrete waste products from the blood through urine [9].

Agrochemicals and fertilizers are the most sensible source for heavy metal distribution in the paddy soil [13]. Insecticides, herbicides, and fungicides are the primary sources of $\mathrm{Cu}, \mathrm{Zn}, \mathrm{Cd}, \mathrm{Pb}$, and $\mathrm{As}$ in the agricultural soil. Phosphate, nitrate, potash, and lime fertilizers are the main sources of $\mathrm{Cr}, \mathrm{Cd}, \mathrm{Cu}, \mathrm{Ni}, \mathrm{Zn}, \mathrm{Mn}$, and $\mathrm{Pb}$ [14].

Moreover, identifying the current status of the toxic metal contamination in drinking water and agricultural soil is more significant because toxic metals can directly enter the human body via drinking water and human food chains can be contaminated with toxic metals via polluted agricultural soil. In order to identify the sources of the toxic metals, assessment of the frequently use fertilizers is more essential as selected areas are fully agricultural areas. Along with it, this study is expected to update the water and agricultural soil contamination levels and the current status of heavy metal pollution in two CKDu endemic areas in Sri Lanka with respect to the reference area (CKDu nonendemic) and illustrate and give a better understanding on heavy metal exposure using index-based assessment of drinking water and the agricultural soil. This comparison mainly focused on revealing a piece of evidence of the contribution of toxic metals to the prevalence of CKDu in selected endemic areas.

\section{Materials and Methods}

2.1. Study Areas and Selection of Sampling Sites. Two (02) $\mathrm{CKDu}$ endemic areas including Ambagaswewa GND $\left(8^{\circ} 11^{\prime} 30.70^{\prime \prime} \mathrm{N}, 81^{\circ} 0^{\prime} 57.08^{\prime \prime} \mathrm{E}\right)$ in Polonnaruwa District and Eppawala GND $\left(8^{\circ} 8^{\prime} 40.10^{\prime \prime} \mathrm{N}, 80^{\circ} 24^{\prime} 37.73^{\prime \prime} \mathrm{E}\right)$ in Anuradhapura District and a reference area that is Dambethalawa GND $\left(7^{\circ} 17^{\prime} 1.68^{\prime \prime} \mathrm{N}, 81^{\circ} 32^{\prime} 52.35^{\prime \prime} \mathrm{E}\right)$ in Ampara District in Sri Lanka were selected for the sampling based on the recent hospital data obtained from the Ministry of
Health, Sri Lanka. GPS coordinates were recorded at each and every sampling location using a GPS device. All sampling procedures were done in April 2019 (dry season).

2.2. Sampling. Sampling points for the drinking water sample collection were selected from shallow drinking water wells (dug wells) located in the home gardens of the residents which are the main sources of water consumption in their daily life. Thirty drinking water samples were collected from each CKDu hot spot and the reference site for the analysis of cations and anions. All the water samples were collected into prewashed Teflon bottles for analysis and acidified with ultrapure nitric acid (2\% v/v) (Sinopharm, Shanghai, China). All the water samples were stored at $4^{\circ} \mathrm{C}$ during transport to the laboratory. Agricultural lands were selected for soil sampling, and twenty composite topsoil samples were collected from the paddy cultivated fields according to the random sampling method in each selected CKDu hotspot and the reference site. Composite soil samples were prepared by a combination of five samples from each location. As frequently used fertilizers in paddy cultivations, urea, potash, and triple superphosphate fertilizer samples were collected from the stores in selected $\mathrm{CKDu}$ endemic areas. Fifteen composite fertilizer samples were collected in each type of fertilizers.

2.3. Analysis. Concentrations of metal elements in drinking water including $\mathrm{Mn}, \mathrm{Co}, \mathrm{As}, \mathrm{Cd}, \mathrm{Pb}, \mathrm{Cu}, \mathrm{Zn}, \mathrm{Na}, \mathrm{K}, \mathrm{Al}, \mathrm{Ca}$, $\mathrm{Mg}, \mathrm{Fe}$, and $\mathrm{Ni}$ were determined using inductively coupled plasma mass spectrometry (ICP-MS-7800-Agilent, Germany). Multielement ICP-MS standards (AccuStandard, USA) were used for the instrumental calibration. Two calibration series (0.1 ppb-10 ppb and $10 \mathrm{ppb}$ to $1000 \mathrm{ppb}$ ) were prepared using multielement standard. Acidified water samples with conc. $\mathrm{HNO}_{3}(69 \%$ purity, Sigma-Aldrich, India) were filtered through $0.45 \mu \mathrm{m}$ syringe filters before the insertion to the ICP-MS instrument. The concentrations of anions in water samples (including fluoride, chloride, nitrate, phosphate, and sulfate) and fluoride, chloride, nitrate, and sulfate contents in soil samples were measured using ion chromatography. Sodium bicarbonate (Sigma-Aldrich, India, CASRN 144-55-8) and sodium carbonate (SigmaAldrich, India, CASRN-497-19-7) were used as elution solution, and sulfuric acid (Sigma-Aldrich, India, CASRN7664-93-9) was used as regeneration solution. ACS reagent grade $1000 \mathrm{mg} / \mathrm{L}$ stock solutions of considered counterions were used to prepare the standards and prepared for a range of concentrations encompassing expected sample concentrations. Standards and collected samples were filtered. A small volume of the sample $(5.0 \mathrm{~mL})$ was introduced, under the flow rate of $0.7 \mathrm{~mL} / \mathrm{min}$ into the ion chromatograph (Metrohm Eco IC, Switzerland), and the anions of interest were separated and measured, using a system comprised of a guard column, analytical column, suppressor device, and conductivity detector.

$0.200 \mathrm{~g}$ of each soil sample was digested using a microwave digester (ETHOS EASY, Italy) with adding $10.00 \mathrm{~mL}$ of concentrated nitric acid. Digested solutions 
were diluted up to $25.00 \mathrm{~mL}$ with ultrapure water, and $10.00 \mathrm{~mL}$ of each digested soil solution was filtered through $0.45 \mu \mathrm{m}$ nylon syringe filters. The determination of cation concentrations ( $\mathrm{Cr}, \mathrm{Mn}, \mathrm{Fe}, \mathrm{Co}, \mathrm{As}, \mathrm{Cd}, \mathrm{Pb}, \mathrm{Cu}, \mathrm{Zn}, \mathrm{Mg}, \mathrm{Ca}$, $\mathrm{Na}, \mathrm{K}$, and $\mathrm{Ni}$ ) in soil samples was carried out by the ICP-MS method (ICP-MS-8000-Agilent, Germany). The calibration series $(1 \mathrm{ppm}-50 \mathrm{ppm})$ was prepared using multielement standard, and $0.200 \mathrm{~g}$ of each fertilizer sample (Urea, Potash, and Triple Superphosphate) was also used for the analysis of heavy metal/metalloids ( $\mathrm{Cr}, \mathrm{Mn}, \mathrm{Fe}, \mathrm{Cu}, \mathrm{Zn}, \mathrm{As}, \mathrm{Cd}$, and $\mathrm{Pb}$ ) concentrations by the ICP-MS method.

In order to determine the total phosphate concentration in the soil, $0.02 \mathrm{M}$ Truog extracting solution was prepared, $26.54 \mathrm{~g}$ of $\left(\mathrm{NH}_{4}\right)_{6} \mathrm{Mo}_{7} \mathrm{O}_{24} \cdot 4 \mathrm{H}_{2} \mathrm{O}$ (Sigma-Aldrich, India) was dissolved in $200 \mathrm{~mL}$ of distilled water (warmed to $60^{\circ} \mathrm{C}$ ), and $280.0 \mathrm{~mL}$ Conc. $\mathrm{H}_{2} \mathrm{SO}_{4}$ (95-97\% purity, EMPARTA ${ }^{\circledR}$ ACS, India) was diluted with $750 \mathrm{ml}$ of distilled water. After both solutions cooled down to room temperature, ammonium molybdate solution was added slowly to the sulfuric acid solution with shaking to prepare the molybdate reagent (2.5\%). $2.5 \mathrm{~g}$ of $\mathrm{SnCl}_{2} \cdot 2 \mathrm{H}_{2} \mathrm{O}$ (Sigma-Aldrich, India) was dissolved in $10.0 \mathrm{~mL}$ of concentrated $\mathrm{HCl}$ and diluted to $100 \mathrm{~mL}$ with distilled water by rapid stirring. A few pieces of metallic tin (Sn) were added to the solution after filtration to prepare stannous chloride solution. A $100.0 \mathrm{mg} / \mathrm{L}$ standard phosphorus solution was prepared by dissolving $0.4394 \mathrm{~g}$ of $\mathrm{KH}_{2} \mathrm{PO}_{4}$ (Sigma-Aldrich, India) in $1 \mathrm{~L}$ of $\mathrm{H}_{2} \mathrm{SO}_{4}(0.01 \mathrm{~mol} /$ $\mathrm{L}$ ), and a $4.0 \mathrm{mg} / \mathrm{L}$ solution was prepared as a phosphorus working solution.

Using the phosphorus working solution, a calibration curve was constructed for the UV-visible spectrophotometer and measured the absorbance at $660 \mathrm{~nm}$ using a UV-visible spectrophotometer (Agilent Cary 3500, Germany). Soil samples for the phosphate analysis were prepared by adding $3.0 \mathrm{~g}$ of a soil sample to the $100.00 \mathrm{~mL}$ extracting solution. The mixture was shaken for about 10 minutes and allowed to stand for 15 minutes followed by filtration. Both reagents were mixed with the $50.00 \mathrm{~mL}$ aliquot of each soil solution and measured the absorbance at $660 \mathrm{~nm}$.

2.4. Indexing Approach. The present study attempts to use the weighted arithmetic average mean method for calculating the HPI for the purpose of monitoring drinking water contamination levels in CKDu affected areas with respect to the reference combining the concentrations of $\mathrm{Cr}, \mathrm{Mn}, \mathrm{Cu}, \mathrm{Fe}, \mathrm{Pb}, \mathrm{Cd}, \mathrm{As}$, and $\mathrm{Zn}$. A set of equations were incorporated in calculating HPI for the drinking water samples. The critical pollution index value is 100 , where higher HPI values indicate the greater damage to human health.

The HPI model [15] was calculated as

$$
\mathrm{HPI}=\frac{\sum_{i=1}^{n} W_{i} * Q_{i}}{\sum_{i=1}^{n} W_{i}},
$$

where $Q$ is the subindex of the $i^{\text {th }}$ parameter, $W_{i}$ is the unit weight of the $i^{\text {th }}$ parameter, and $n$ is the number of parameters considered.

$$
W_{i}=\frac{k}{S_{i}},
$$

where $W_{i}$ is the unit of weightage, $k$ is the constant of proportionality $(k=1)$, and $S_{i}$ is the recommended standard for the $i^{\text {th }}$ parameter according to the Sri Lankan standards for the drinking water.

The subindex $\left(Q_{i}\right)$ of the $i^{\text {th }}$ parameter was calculated according to Reza and Singh [6]:

$$
Q_{i}=\frac{\left|M_{i}-I_{i}\right|}{S_{i}-I_{i}} * 100,
$$

where $M_{i}$ is the monitored value of the heavy metal of $i^{\text {th }}$ parameter in ppb, $I_{i}$ is the maximum desirable value (ideal) of the $i^{\text {th }}$ parameter, and $S_{i}$ refers to the standard or permissible limit for the $i^{\text {th }}$ parameter.

2.5. Geoaccumulation Index (Igeo for Agricultural Soil. Geoaccumulation value was developed for the determination of the degree of metal concentrations and the pollution which is caused by the metals in soil segregates. Geoaccumulation index $\left(I_{\text {geo }}\right)$ was determined using the following equation [16] (Muller, 1979):

$$
I_{\text {geo }}=\frac{C_{n}}{1.5 \times B_{n}}
$$

where $C_{n}$ is the measured concentration of the element in soil dust, $B_{n}$ is the geochemical background value, and the constant 1.5 allows us to analyze natural fluctuations in the content of a given substance in the environment and to detect a very small anthropogenic influence.

2.6. Natural Background Concentration (NBC). NBC can be calculated by the method described by Ander et al., 2013 [17].

$$
\mathrm{NBC}=\frac{x+(1.96 * \mathrm{SD})}{\sqrt{n}},
$$

where $x$ is the sample mean, SD is the standard deviation, and $n$ is the number of samples. $I_{\text {geo }}$ was distinguished into seven classes by Muller: Table 1 represents the seven classes of geoaccumulation index by Muller.

2.7. Geographical Data Treatment. Geographic Information System (GIS) is widely used for collecting diverse spatial data and for overlay analysis in the spatial register domain to represent spatially variable phenomena [18-20]. GIS, which synthesizes different and important quality data into an easily understood format, provides a way to summarize overall water or soil quality conditions in a manner that can be clearly communicated to policymakers [21] and finally can be incorporated with the decision-making process. The maps which show the spatial distribution of heavy metal pollution in selected sampling areas were interpolated by the Inverse Distance Weighted (IDW) tool and the Spatial 
TABLE 1: Classes of geoaccumulation index (Muller, 1979).

\begin{tabular}{ccc}
\hline$I_{\text {geo }}$ & $I_{\text {geo }}$ class & Soil/sediment quality \\
\hline $0-0$ & 0 & Unpolluted \\
$0-1$ & 1 & Unpolluted to moderately polluted \\
$1-2$ & 2 & Moderately polluted \\
$2-3$ & 3 & Moderately polluted to highly polluted \\
$3-4$ & 4 & Highly polluted \\
$4-5$ & 5 & Highly polluted to very highly polluted \\
$5-6$ & $>5$ & Very highly polluted \\
\hline
\end{tabular}

Autocorrelation tool (Moran's index) using ArcGIS 10.2 software.

\section{Results and Discussion}

3.1. Assessment of Drinking Water. In the drinking water scenario, the priority should be given to the fluoride toxicity because there have been many cases reported which were related to human kidney function failure due to fluoride toxicity. In accordance with the literature, an investigation of 210 children in China found that drinking water with more than $2.00 \mathrm{mg} / \mathrm{L}$ fluoride had increased levels of $\mathrm{N}$-acetyl glucosamine (NAG) and y-glutamyl transpeptidase (yGT) in their urine, both of which are markers of renal tubular damage [22]. The present study has found that mean fluoride contents in the $\mathrm{CKDu}$ endemic areas have exceeded the permissible limits for drinking water fluoride $(1.00 \mathrm{mg} / \mathrm{L})$ (SLS 614:2013) (Figure 1).

The mean concentrations of other counterions which were analyzed in drinking water samples such as $\mathrm{Cl}^{-}, \mathrm{Br}^{-}$, $\mathrm{NO}_{3}^{-}, \mathrm{PO}_{4}^{3-}$, and $\mathrm{SO}_{4}^{3-}$ (Table 2) have not exceeded permissible limits defined in the Sri Lankan drinking water quality standards (SLS 614:2013) in both endemic and nonendemic areas. However, Chandrajith et al., 2010, mentioned that even though no single geochemical parameter could be clearly and directly correlated with the etiology of $\mathrm{CKDu}$, the unique hydrogeochemistry of the drinking water is closely associated with the incidence of the disease. In affected areas, water quality needs to be assessed, particularly combinations of various constituents, such as metal elements and the hardness in combination [4].

According to the primary data gathered from both $\mathrm{CKDu}$ affected areas (Table 3), Cd, As, $\mathrm{Pb}, \mathrm{Cr}, \mathrm{Cu}$, and $\mathrm{Zn}$ concentrations of drinking water were below the Sri Lankan drinking water quality guidelines [23] in the average, median, maximum, and minimum. According to the literature review of the study, another drinking water quality analysis has been conducted by a research group from Iran, and their studies also revealed that the concentrations of $\mathrm{As}, \mathrm{Cd}, \mathrm{Cr}$, $\mathrm{Pb}, \mathrm{Mn}, \mathrm{Zn}, \mathrm{Cu}$, and $\mathrm{Fe}$ in drinking water were also lower than the maximum allowed concentrations advised by the USEPA and WHO [22].

Additionally, average cadmium and lead concentrations in drinking water of both $\mathrm{CKDu}$ endemic areas were significantly higher $(p<0.05)$ than those of the reference area. Although the metal contents were found in low levels in drinking water in $\mathrm{CKDu}$ endemic areas, long-term exposure via drinking water may have harmful effects of etiological significance for $\mathrm{CKDu}$ due to bioaccumulation and dehydration.

In recent years, much attention has been given toward the evaluation of heavy metal pollution in ground and surface water with the development of a heavy metal pollution index (HPI) [24]. In order to evaluate the suitability of the water for drinking, the HPI of the drinking water in both $\mathrm{CKDu}$ endemic areas can be considered. The calculated HPI values were high in water from Eppawala GND which was ranging between 21.4 and 30.7. The higher values of HPI may be attributed due to the natural Apatite ore which is located in Eppawala, Sri Lanka. HPI for Ambagaswewa GND ranged from 25.2 to 27.8, and according to Moran's index, values resulted from the Spatial Autocorrelation tool showed that the heavy metal pollution in sampled drinking water sources tends to be clustered throughout Ambagaswewa GND with the higher concentrations. Lower HPI values were recorded in Dambethalawa GND in Ampara district (reference site) where no CKDu patients were recorded (Figure 2).

However, considering the classes of HPI, all the sampling locations fall under the medium range (HPI 15-40). This indicates that water is not critically polluted with respect to nephrotoxic heavy metals because the critical value of the HPI is 100 [15].

3.2. Evaluation of Agricultural Soil. In the soil, metals are found in different forms such as inorganic compounds, metal complexes, and organometallic compounds. When these metal compounds dissolve in water, they dissociate into ions and tend to behave like cations; they become part of the exchange complex and are available for absorption in plants, by displacing the essential cations $[25,26]$. In paddy cultivated agricultural soils in Eppawala GND, the total average concentrations of toxic metals or metalloid/s carried a sequence of $\mathrm{Cr}>\mathrm{Zn}>\mathrm{Cu}>\mathrm{Pb}>\mathrm{As}>\mathrm{Cd}$. The total average concentrations of toxic metals or metalloid/s in the agricultural soils in Ambagaswewa GND carried a sequence of $\mathrm{Zn}>\mathrm{Cu}>\mathrm{Cr}>\mathrm{Pb}>\mathrm{As}>\mathrm{Cd}$ (Table 4). However, the results indicate the total amount of toxic metals/metalloids in the paddy soil samples, and some fraction may be absorbed by the crop plants from the soil solution depending on the conditions of the soil environment.

According to the paired $t$-test outcomes between $\mathrm{CKDu}$ prevalence areas and the reference, the concentrations of $\mathrm{Cr}$, As, and Cd of paddy soil in both CKDu hotspots were significantly higher than those of Dambethalawa GND (the reference) (at 95\% confidence interval). All those three contaminants are considered nephrotoxic contaminants, and synthetic agrochemicals are known to be the main sources of heavy metal pollution in agricultural areas [27].

Mineral fertilizers used as a source of nutrients for plants may sometimes have a negative impact on the environment, mainly on soil and water. Soil pollution with heavy metals is particularly dangerous [28]. Small contents of these metals in nitrogen and potassium fertilizers do not pose any hazard of soil or plant contamination; however, phosphorus and multicomponent fertilizers used for soil deacidification are 

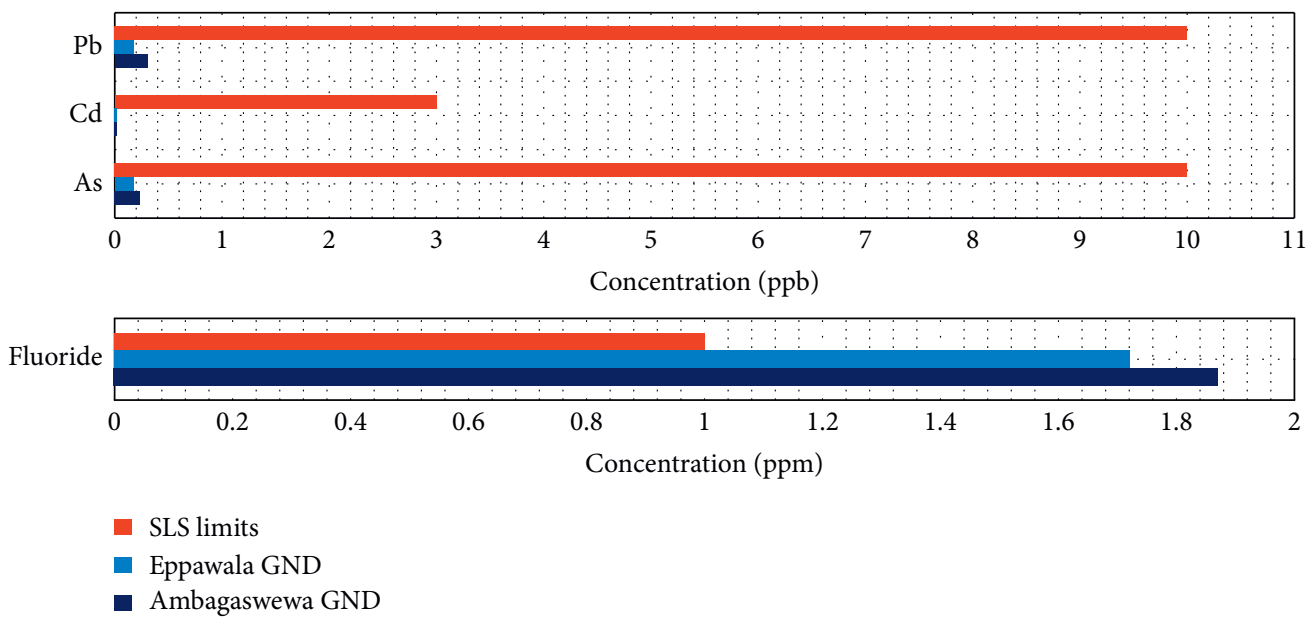

FIGURE 1: Graphical representation of lead, cadmium, arsenic concentrations, and fluoride content in collected drinking water samples in both CKDu hotspots: Eppawala GND and Ambagasewewa GND.

TABle 2: Statistical evaluation of counterions of the drinking water sources in the selected CKDu prevalence areas: Eppawala (EP) and Ambagaswewa (AM) GNDs and the reference (RE).

\begin{tabular}{|c|c|c|c|c|c|}
\hline Variable & Sampling site & Mean & SE mean & Minimum & Maximum \\
\hline \multirow{3}{*}{ Fluoride $(\mathrm{mg} / \mathrm{L})$} & $\mathrm{EP}$ & 1.87 & 0.17 & 0.09 & 3.98 \\
\hline & $\mathrm{AM}$ & 1.72 & 0.15 & 0.05 & 4.00 \\
\hline & $\mathrm{RE}$ & 0.40 & 0.03 & 0.10 & 1.10 \\
\hline \multirow{3}{*}{ Chloride (mg/L) } & $\mathrm{EP}$ & 112 & 13.3 & 18.2 & 357 \\
\hline & $\mathrm{AM}$ & 42.0 & 5.73 & 0.70 & 135 \\
\hline & $\mathrm{RE}$ & 69.8 & 48.3 & 1.20 & 117 \\
\hline \multirow{3}{*}{ Bromide (mg/L) } & EP & 0.20 & 0.06 & ND & 1.48 \\
\hline & $\mathrm{AM}$ & 0.12 & 0.06 & ND & 1.70 \\
\hline & $\mathrm{RE}$ & ND & 0.00 & ND & 0.00 \\
\hline \multirow{3}{*}{ Nitrate $(\mathrm{mg} / \mathrm{L})$} & EP & 3.47 & 0.66 & ND & 18.4 \\
\hline & $\mathrm{AM}$ & 3.24 & 0.20 & 0.39 & 6.08 \\
\hline & $\mathrm{RE}$ & 1.70 & 0.49 & 0.16 & 11.8 \\
\hline \multirow{3}{*}{ Phosphate (mg/L) } & $\mathrm{EP}$ & ND & - & ND & ND \\
\hline & $\mathrm{AM}$ & ND & - & ND & $\mathrm{ND}$ \\
\hline & $\mathrm{RE}$ & ND & - & ND & ND \\
\hline \multirow{3}{*}{ Sulfate $(\mu \mathrm{g} / \mathrm{L})$} & $\mathrm{EP}$ & 37.2 & 5.60 & 1.30 & 258 \\
\hline & $\mathrm{AM}$ & 31.6 & 3.75 & ND & 99.3 \\
\hline & $\mathrm{RE}$ & 30.1 & 19.2 & ND & 67.0 \\
\hline
\end{tabular}

ND: not detected.

usually a significant factor in heavy metal balance in the environment [10, 29].

Therefore, Pearson's correlation was done on the available metals present in the sampled agricultural soils and phosphorus content in those soil samples to check whether there is a possible relationship between soil phosphorus content and the available metal contents. The correlation matrix of soil phosphate and heavy metals in selected paddy grown agricultural areas is shown in Table 5. According to the results of the correlation matrix, there was a significant positive correlation between available soil phosphate content and cadmium and chromium concentrations in agricultural soils (significant at $p=0.05$ and $p=0.01$, respectively). This correlation may be a result of the sulfuric acid used at manufacturing fertilizers containing phosphorus in a watersoluble form. During chemical processing of these minerals, mostly cadmium and chromium pass into the soluble phase and then, as a result of the technological process, to the fertilizers. Therefore, the rates of usage of phosphorus and multicomponent fertilizers are usually determined on the basis of their phosphorus contents, and there is a direct connection between phosphorus content and an increase in heavy metal concentrations in agricultural soil. Even worse, the fertilizers do not replace the trace minerals resulting in mineral-depleted soil. When paddy grows in mineral-depleted soil, it easily absorbs metals like Cd which is too toxic to the human kidneys [30].

Apart from that, the prolonged exposure of crop plants in soils with heavy metals increases their absorption capacity and depends on factors such as $\mathrm{pH}$, cation exchange capacity, organic matter content, clay content, and redox potential; these determine the soil capacity to retain or 
TABLE 3: Statistical evaluation of concentrations of selected toxic metals/metalloids of the drinking water sources in the selected areas: Eppawala (EP) and Ambagaswewa (AM) GNDs and the reference (RE).

\begin{tabular}{|c|c|c|c|c|c|c|}
\hline Metal element & Sample & Mean & \pm SE mean & Minimum & Median & Maximum \\
\hline \multirow{3}{*}{$\mathrm{Cr}(\mu \mathrm{g} / \mathrm{L})$} & $\mathrm{EP}$ & 0.27 & 0.03 & 0.02 & 0.13 & 0.66 \\
\hline & $\mathrm{AM}$ & 0.26 & 0.05 & 0.01 & 0.13 & 1.13 \\
\hline & $\mathrm{RE}$ & 0.22 & 0.03 & 0.05 & 0.25 & 0.65 \\
\hline \multirow{3}{*}{$\operatorname{Mn}(\mu \mathrm{g} / \mathrm{L})$} & $\mathrm{EP}$ & 157 & 25.6 & 0.30 & 25.0 & 485 \\
\hline & $\mathrm{AM}$ & 62.0 & 9.46 & 0.10 & 19.5 & 163 \\
\hline & $\mathrm{RE}$ & 129 & 19.5 & 0.20 & 189 & 122 \\
\hline \multirow{3}{*}{$\mathrm{Fe}(\mu \mathrm{g} / \mathrm{L})$} & $\mathrm{EP}$ & 135 & 38.9 & 0.00 & 89.5 & 867 \\
\hline & $\mathrm{AM}$ & 60.6 & 13.7 & 0.40 & 16.2 & 305 \\
\hline & $\mathrm{RE}$ & 260 & 41.3 & 0.60 & 189 & 299 \\
\hline \multirow{3}{*}{$\mathrm{Cu}(\mu \mathrm{g} / \mathrm{L})$} & $\mathrm{EP}$ & 1.37 & 0.16 & 0.49 & 0.96 & 4.59 \\
\hline & $\mathrm{AM}$ & 0.67 & 0.05 & 0.21 & 0.65 & 1.25 \\
\hline & $\mathrm{RE}$ & 0.98 & 0.09 & ND & 0.88 & 2.88 \\
\hline \multirow{3}{*}{ As $(\mu \mathrm{g} / \mathrm{L})$} & $\mathrm{EP}$ & 0.25 & 0.30 & 0.03 & 0.19 & 0.68 \\
\hline & $\mathrm{AM}$ & 0.19 & 0.02 & ND & 0.15 & 0.57 \\
\hline & $\mathrm{RE}$ & 0.55 & 0.08 & 0.05 & 0.72 & 2.29 \\
\hline \multirow{3}{*}{$\mathrm{Cd}(\mu \mathrm{g} / \mathrm{L})$} & $\mathrm{EP}$ & 0.07 & 0.00 & ND & 0.06 & 0.07 \\
\hline & $\mathrm{AM}$ & 0.02 & 0.00 & ND & 0.01 & 0.13 \\
\hline & $\mathrm{RE}$ & 0.01 & 0.02 & ND & 0.34 & 0.45 \\
\hline \multirow{3}{*}{$\mathrm{Pb}(\mu \mathrm{g} / \mathrm{L})$} & $\mathrm{EP}$ & 0.32 & 0.07 & ND & $\mathrm{ND}$ & 1.78 \\
\hline & $\mathrm{AM}$ & 0.20 & 0.02 & 0.05 & 0.14 & 0.66 \\
\hline & $\mathrm{RE}$ & 0.15 & 0.16 & 0.07 & 0.21 & 0.48 \\
\hline \multirow{3}{*}{$\mathrm{Zn}(\mu \mathrm{g} /)$} & $\mathrm{EP}$ & 40.0 & 10.3 & 2.60 & 18.3 & 289 \\
\hline & $\mathrm{AM}$ & 12.0 & 1.73 & 1.32 & 6.53 & 38.9 \\
\hline & $\mathrm{RE}$ & 30.7 & 8.16 & 0.91 & 6.58 & 106 \\
\hline
\end{tabular}

ND: not detected.

mobilize heavy metals [31]. Heavy metals in trace amounts can accumulate in soils of agricultural areas, due to their characteristics and buffering capacity $[32,33]$.

The risks, the degree of toxicity, and the persistence of the metals depend on the impact which soils receive by different anthropogenic activities. The use and application of geoaccumulation indexes $\left(I_{\text {geo }}\right)$ will identify the source of pollutants and the degree of bioaccumulation in soil [34] (Figure 3).

For all considered metals in the studied samples (for $\mathrm{CKDu}$ endemic areas), the $I_{\text {geo }}$ values presented the decreasing order of $\mathrm{As}>\mathrm{Pb}>\mathrm{Cu}>\mathrm{Ni}>\mathrm{Cr}>\mathrm{Zn}>\mathrm{Cd}$ for Eppawala GND and for Ambagaswewa GND, and the $I_{\text {geo }}$ values presented the decreasing order of $\mathrm{As}>\mathrm{Cu}>\mathrm{Cr}>\mathrm{Ni}>\mathrm{Cd}>\mathrm{Pb}>\mathrm{Zn}$. The mean $I_{\text {geo }}$ values of all the studied metals in all sampling sites indicate that the soils are slowly contaminated with heavy metals. A trend like this was also revealed in another study of agricultural soil analysis. Rostami et al. depict that agricultural soil was contaminated by $\mathrm{Cr}, \mathrm{Cu}, \mathrm{Ni}, \mathrm{Pb}$, and $\mathrm{Zn}$ but was moderately contaminated by $\mathrm{Cd}$ and As when considering the $I_{\text {geo }}$ for the soil [34].

According to the findings, soil samples from both $\mathrm{CKDu}$ prevalence areas and the reference area have moderately contaminated/polluted with the metal contaminants and belong to class 1 . However, none of the selected area's paddy soil has exceeded the class 2 contamination level. And also most of the $I_{\text {geo }}$ values of the paddy soil in the CKDu nonendemic area (reference) were much low with respect to $\mathrm{CKDu}$ endemic areas, and agricultural soil in $\mathrm{CKDu}$ endemic areas tends to convert to the contaminated position with some heavy metals.

Those metal contaminants are important since they are capable of decreasing crop production due to the risk of bioaccumulation and biomagnification in the food chain, and there is also a risk of superficial and groundwater contamination [8]. Therefore, remediation of agricultural soil contaminated by heavy metals is necessary in order to reduce the associated health risks, make the land resource available for agricultural production, and enhance food security.

3.3. Assessment of Toxic Metals in Commonly Used Fertilizers in Sri Lanka. Another problematic case is agrochemicals including fertilizers and pesticides which were introduced to Sri Lanka in the 1970s. Sri Lankan scientists reported that paddy soils in Mahaweli development areas (most of the $\mathrm{CKDu}$ endemic areas) are polluted with potentially toxic metals, and paddy soils in Sri Lanka are highly modified by artificial fertilizer applications [35]. Table 6 shows the contribution of the commonly used fertilizers to toxic metal contamination in the soil in Sri Lanka. According to that, urea which is commonly used in paddy cultivation as well as other cultivations in Sri Lanka has contained toxic metals such as $\mathrm{Cd}, \mathrm{As}, \mathrm{Cr}, \mathrm{Pb}, \mathrm{Zn}$, and $\mathrm{Cu}$ in noticeable amounts. Apart from that, potash and triple superphosphate that are applied in the paddy cultivation also have contained significant amounts of the aforementioned toxic metals except 


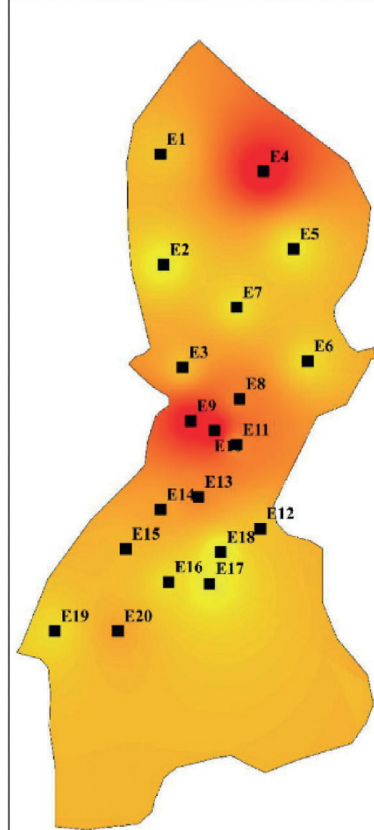

(a)

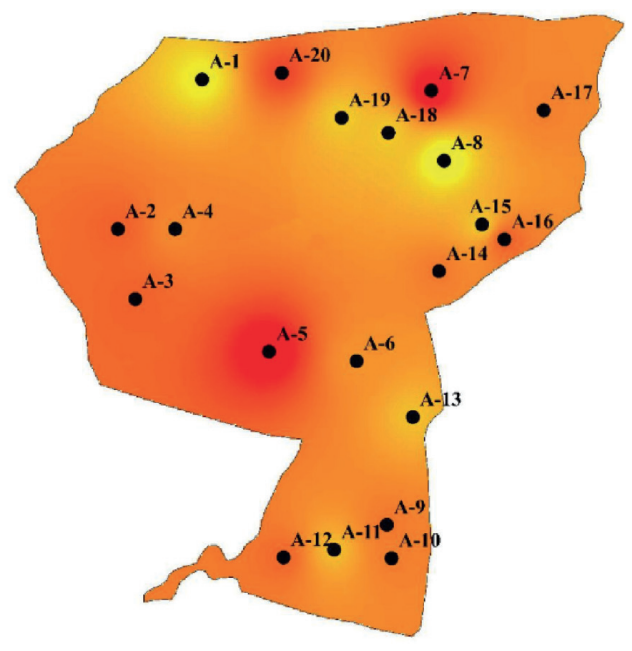

(b)

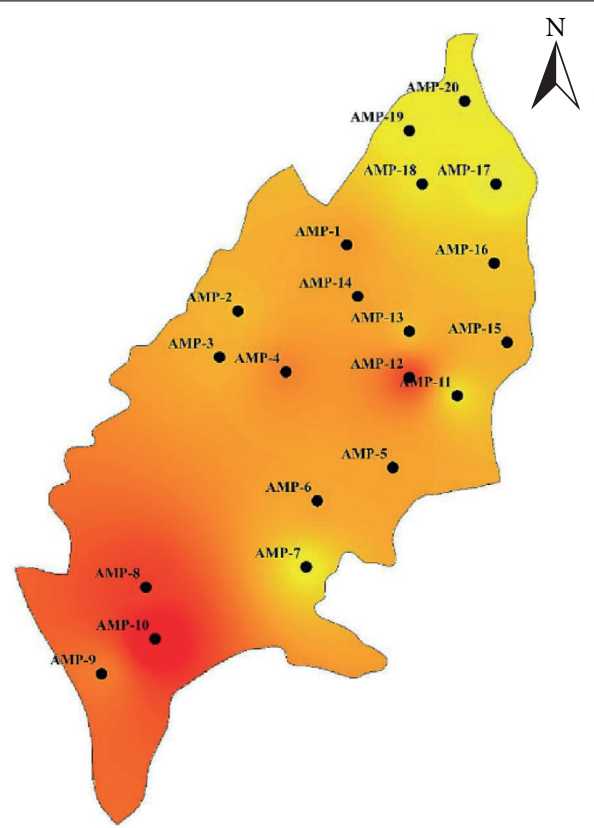

(c)

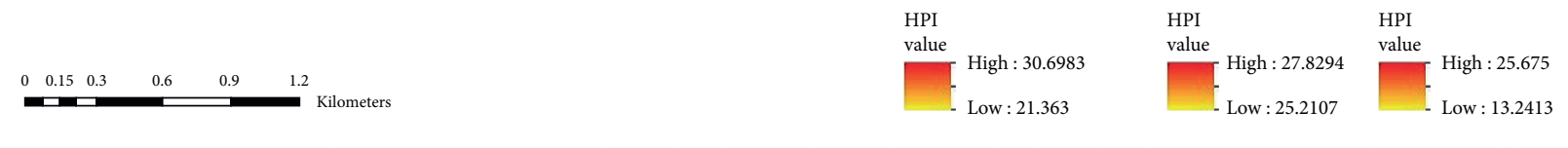

- Eppawala points Eppawala GND
- Ambagaswewa points Ambagaswewa GND
- Dambetalawa points Dambetalawa GND

FIGURE 2: Interpolation of heavy metal pollution index (HPI) in sampling location via drinking water analysis: (a) Eppawala GND in Anuradhapura district, (b) Ambagaswewa GND in Polonnaruwa district, and (c) Dambethalawa GND in Ampara district (the reference).

TABLE 4: Descriptive statistics on concentrations of environmental toxicants including toxic metals/metalloids and phosphates of paddy soil samples (CKDu hotspots: Eppawala (EP) and Ambagaswewa (AM) GNDs, and the reference: Dambethalawa (RE) GND).

\begin{tabular}{|c|c|c|c|c|c|c|}
\hline Variable & Sample & Mean & SE mean & Minimum & Median & Maximum \\
\hline \multirow{3}{*}{$\mathrm{Cr}(\mathrm{mg} / \mathrm{kg})$} & EP & 49.9 & 2.12 & 32.6 & 49.9 & 64.2 \\
\hline & $\mathrm{AM}$ & 33.0 & 2.01 & 19.6 & 30.6 & 48.4 \\
\hline & $\mathrm{RE}$ & 8.87 & 1.19 & 3.59 & 7.80 & 24.1 \\
\hline \multirow{3}{*}{$\mathrm{Mn}(\mathrm{mg} / \mathrm{kg})$} & $\mathrm{EP}$ & 302 & 29.9 & 164 & 273 & 611 \\
\hline & $\mathrm{AM}$ & 590 & 203 & 173 & 397 & 3325 \\
\hline & $\mathrm{RE}$ & 125 & 24.6 & 18.5 & 96.3 & 417 \\
\hline \multirow{3}{*}{$\mathrm{Fe}(\mathrm{mg} / \mathrm{kg})$} & $\mathrm{EP}$ & 23765 & 1142 & 15052 & 24075 & 30728 \\
\hline & $\mathrm{AM}$ & 30461 & 5103 & 12995 & 25735 & 95805 \\
\hline & $\mathrm{RE}$ & 7117 & 1178 & 2627 & 5799 & 22581 \\
\hline \multirow{3}{*}{ Co $(\mathrm{mg} / \mathrm{kg})$} & $\mathrm{EP}$ & 8.08 & 0.51 & 4.73 & 7.81 & 12.0 \\
\hline & $\mathrm{AM}$ & 13.8 & 1.50 & 5.90 & 14.1 & 21.6 \\
\hline & $\mathrm{RE}$ & 3.35 & 0.64 & 0.93 & 2.90 & 11.5 \\
\hline \multirow{3}{*}{ As (mg/kg) } & $\mathrm{EP}$ & 5.03 & 0.12 & 4.04 & 5.08 & 5.65 \\
\hline & $\mathrm{AM}$ & 3.30 & 2.23 & 0.57 & 0.97 & 34.4 \\
\hline & $\mathrm{RE}$ & 0.48 & 0.04 & 0.22 & 0.45 & 0.84 \\
\hline \multirow{3}{*}{$\mathrm{Cd}(\mathrm{mg} / \mathrm{kg})$} & $\mathrm{EP}$ & 0.11 & 0.01 & 0.08 & 0.09 & 0.25 \\
\hline & $\mathrm{AM}$ & 0.10 & 0.01 & 0.04 & 0.10 & 0.22 \\
\hline & $\mathrm{RE}$ & 0.04 & 0.000 & 0.02 & 0.04 & 0.08 \\
\hline \multirow{3}{*}{$\mathrm{Ca}(\mathrm{mg} / \mathrm{kg})$} & $\mathrm{EP}$ & 4290 & 171 & 3090 & 4376 & 5355 \\
\hline & $\mathrm{AM}$ & 2288 & 1895 & 136 & 268 & 28762 \\
\hline & $\mathrm{RE}$ & 59.35 & 9.71 & 28.7 & 50.0 & 177 \\
\hline
\end{tabular}


TABle 4: Continued.

\begin{tabular}{|c|c|c|c|c|c|c|}
\hline Variable & Sample & Mean & SE mean & Minimum & Median & Maximum \\
\hline \multirow{3}{*}{$\mathrm{Mg}(\mathrm{mg} / \mathrm{kg})$} & $\mathrm{EP}$ & 2359 & 103 & 1495 & 2339 & 2827 \\
\hline & $\mathrm{AM}$ & 1659 & 185 & 710 & 1654 & 3190 \\
\hline & $\mathrm{RE}$ & 651 & 165 & 209 & 497 & 2870 \\
\hline \multirow{3}{*}{$\mathrm{Pb}(\mathrm{mg} / \mathrm{kg})$} & $\mathrm{EP}$ & 9.88 & 0.32 & 6.60 & 10.2 & 11.2 \\
\hline & $\mathrm{AM}$ & 6.80 & 1.20 & 3.52 & 6.26 & 22.7 \\
\hline & $\mathrm{RE}$ & 36.5 & 8.14 & 1.35 & 35.9 & 107 \\
\hline \multirow{3}{*}{$\mathrm{Cu}(\mathrm{mg} / \mathrm{kg})$} & $\mathrm{EP}$ & 24.6 & 0.87 & 15.7 & 25.0 & 28.5 \\
\hline & $\mathrm{AM}$ & 36.4 & 19.9 & 7.70 & 17.8 & 313 \\
\hline & $\mathrm{RE}$ & 2.90 & 0.38 & 1.20 & 2.10 & 5.66 \\
\hline \multirow{3}{*}{$\mathrm{Zn}(\mathrm{mg} / \mathrm{kg})$} & $\mathrm{EP}$ & 34.6 & 1.95 & 27.4 & 32.4 & 59.8 \\
\hline & $\mathrm{AM}$ & 39.4 & 8.74 & 15.1 & 32.3 & 156 \\
\hline & $\mathrm{RE}$ & 14.6 & 2.43 & 8.32 & 11.2 & 39.6 \\
\hline \multirow{3}{*}{$\mathrm{Na}(\mathrm{mg} / \mathrm{kg})$} & $\mathrm{EP}$ & 288 & 14.6 & 207 & 294 & 383 \\
\hline & $\mathrm{AM}$ & 337 & 161 & 84.0 & 186 & 2581 \\
\hline & $\mathrm{RE}$ & 58.5 & 5.23 & 30.1 & 54.8 & 90.9 \\
\hline \multirow{3}{*}{$\mathrm{Al}(\mathrm{mg} / \mathrm{kg})$} & $\mathrm{EP}$ & 26866 & 974 & 17959 & 28426 & 30312 \\
\hline & $\mathrm{AM}$ & 22735 & 2322 & 9511 & 19625 & 44042 \\
\hline & $\mathrm{RE}$ & 1276 & 509 & ND & ND & 4971 \\
\hline \multirow{3}{*}{$\mathrm{K}(\mathrm{mg} / \mathrm{kg})$} & EP & 1106 & 46.9 & 539 & 1125 & 1350 \\
\hline & $\mathrm{AM}$ & 625 & 167 & 235 & 394 & 2799 \\
\hline & $\mathrm{RE}$ & 320 & 62.7 & 135 & 245 & 1155 \\
\hline \multirow{3}{*}{$\mathrm{Ni}(\mathrm{mg} / \mathrm{kg})$} & $\mathrm{EP}$ & 16.9 & 0.63 & 11.1 & 17.4 & 20.2 \\
\hline & $\mathrm{AM}$ & 11.9 & 1.23 & 5.07 & 10.4 & 24.2 \\
\hline & $\mathrm{RE}$ & 1.03 & 0.36 & ND & ND & 3.21 \\
\hline \multirow{3}{*}{$\mathrm{PO}_{4}^{3-}(\mathrm{mg} / \mathrm{kg})$} & $\mathrm{EP}$ & 110 & 6.24 & 61.0 & 111 & 141 \\
\hline & $\mathrm{AM}$ & 8.19 & 0.90 & 3.62 & 7.56 & 16.6 \\
\hline & $\mathrm{RE}$ & 7.94 & 1.48 & 3.00 & 4.96 & 20.5 \\
\hline
\end{tabular}

TABLE 5: Correlation matrix of phosphate and heavy metal concentrations of soil in paddy grown agricultural areas in selected sampling areas.

\begin{tabular}{lccccccccc}
\hline & {$\left[\mathrm{PO}_{4}^{3-}\right]$} & {$[\mathrm{Cd}]$} & {$[\mathrm{Cr}]$} & {$[\mathrm{As}]$} & {$[\mathrm{Pb}]$} & {$[\mathrm{Cu}]$} & {$[\mathrm{Zn}]$} & {$[\mathrm{Fe}]$} & {$[\mathrm{Mn}]$} \\
\hline$\left[\mathrm{PO}_{4}^{3-}\right]$ & - & $0.361^{*}$ & $0.712^{* *}$ & 0.28 & -0.245 & 0.061 & 0.171 & 0.147 \\
{$[\mathrm{Cd}]$} & $0.361^{*}$ & - & $0.473^{* *}$ & -0.197 & $0.576^{* *}$ & $0.250^{*}$ & 0.212 & -0.165 & -0.04 \\
{$[\mathrm{Cr}]$} & $0.712^{* *}$ & $0.473^{* *}$ & - & -0.070 & $0.216^{*}$ & 0.064 & -0.074 & -0.062 & -0.112 \\
{$[\mathrm{As}]$} & 0.28 & -0.197 & -0.070 & - & 0.047 & 0.219 & -0.089 & -0.050 & -0.202 \\
{$[\mathrm{~Pb}]$} & -0.245 & $0.576^{* *}$ & $0.216^{*}$ & 0.047 & - & 0.052 & 0.103 & 0.032 & 0.120 \\
{$[\mathrm{Cu}]$} & 0.061 & $0.250^{*}$ & 0.064 & 0.219 & 0.052 & - & 0.016 & 0.213 \\
{$[\mathrm{Zn}]$} & 0.171 & 0.212 & -0.074 & -0.089 & 0.103 & 0.016 & - & 0.020 \\
{$[\mathrm{Fe}]$} & 0.147 & -0.165 & -0.062 & -0.050 & 0.032 & 0.213 & 0.301 & -0.120 \\
{$[\mathrm{Mn}]$} & -0.040 & -0.337 & -0.112 & -0.202 & 0.120 & 0.020 & -0.120 & 0.045 & 0.045 \\
\hline
\end{tabular}

${ }^{*}$ Correlation is significant at the 0.05 level (2-tailed). ${ }^{* *}$ Correlation is significant at the 0.01 level (2-tailed).

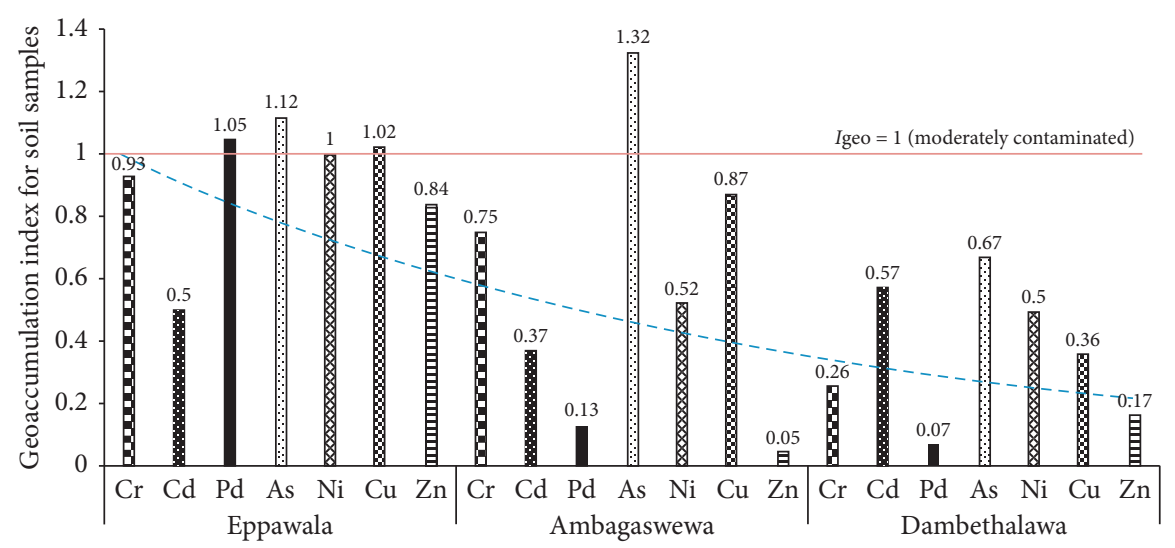

FIGURE 3: Geoaccumulation index $\left(I_{\text {geo }}\right)$ for heavy metals in paddy cultivated soil of selected GN areas. 
TABLE 6: Selected heavy metal/metalloid contents in fertilizer samples collected from the selected CKDu endemic area.

\begin{tabular}{|c|c|c|c|c|c|c|c|c|}
\hline \multirow{2}{*}{ Fertilizer type } & \multicolumn{8}{|c|}{ Mean metal contents in fertilizers \pm SD } \\
\hline & $\mathrm{Cr}(\mathrm{mg} / \mathrm{kg})$ & $\mathrm{Mn}(\mathrm{mg} / \mathrm{kg})$ & $\mathrm{Fe}(\mathrm{mg} / \mathrm{kg})$ & $\mathrm{Cu}(\mathrm{mg} / \mathrm{kg})$ & $\mathrm{Zn}(\mathrm{mg} / \mathrm{kg})$ & As $(\mathrm{mg} / \mathrm{kg})$ & $\mathrm{Cd}(\mathrm{mg} / \mathrm{kg})$ & $\mathrm{Pb}(\mathrm{mg} / \mathrm{kg})$ \\
\hline Urea & $102( \pm 4.17)$ & $\begin{array}{c}2211 \\
( \pm 128.1)\end{array}$ & $\begin{array}{c}2301 \\
( \pm 108.1)\end{array}$ & $21.3( \pm 1.1)$ & $723( \pm 96.5)$ & $\begin{array}{c}59.9 \\
( \pm 2.72)\end{array}$ & $\begin{array}{c}1.74 \\
( \pm 0.14)\end{array}$ & $289( \pm 9.78)$ \\
\hline MOP (muriate of potash) & $83.6( \pm 4.4)$ & $4.20( \pm 0.75)$ & $702( \pm 116.1)$ & $\begin{array}{c}0.58 \\
( \pm 0.17)\end{array}$ & $\begin{array}{c}93.8 \\
( \pm 20.4)\end{array}$ & ND & ND & $\begin{array}{c}6.34 \\
( \pm 1.64)\end{array}$ \\
\hline $\begin{array}{l}\text { TSP (triple } \\
\text { superphosphate) }\end{array}$ & $\begin{array}{c}386 \\
( \pm 44.8)\end{array}$ & $4234( \pm 55.8)$ & $2642( \pm 466)$ & $141( \pm 15.9)$ & $348( \pm 21.9)$ & ND & ND & $124( \pm 14.5)$ \\
\hline
\end{tabular}

ND: not detected.

$\mathrm{Cd}$ and As. Furthermore, the risk of accumulation of toxic metals is augmented due to the limitless application of fertilizers in paddy cultivation. Owing to toxic element contaminated fertilizer application in the paddy areas, tank sediment is also contaminated as a long-term influence. Hence, those toxic metals can be incorporated into human food chains due to the consumption of freshwater fish [36-38].

\section{Conclusions}

Incorporation of the toxic metals into the food chains mainly occurs via contaminated paddy soil in rice consuming regions in the world as major food items such as the Asian region. In this study, selected CKDu endemic areas in Sri Lanka are also identified as an agricultural area, and for the first time, this study compared the hazardous metal contamination of drinking water and agricultural soil in CKDu endemic areas with a nonendemic area in Sri Lanka. Even if the current study reveals that toxic metal contents in drinking water samples in CKDu endemic areas were far below the permissible limits, long-term exposure of the toxic metals via drinking water may generate a risk. Apart from that, the persistence of the toxic metals/metalloids such as $\mathrm{Cr}, \mathrm{As}, \mathrm{Cd}$, and $\mathrm{Pb}$ in frequently applying fertilizers would be the major reason for paddy soil pollution with toxic metals/metalloids. Geoaccumulation indexes reveal that paddy soil in selected CKDu endemic areas is being transferred to a moderate contamination stage, and frequently, metal-contaminated fertilizer applications may augment the risk of entering toxic metals into the paddy plants and then rice grins from the soil solution. Hence, the long-term accumulation of toxic metals/metalloids definitely affects human kidney functions. There is an urgent need to expand the evaluation of the quality of the fertilizers' use in Sri Lanka.

\section{Data Availability}

No data were used to support this study.

\section{Conflicts of Interest}

The authors declare that they have no known competing financial interest or personal relationships that could have appeared to influence the work reported in this paper.

\section{Authors' Contributions}

W. P. R. T. Perera conceptualized the study and performed data analysis and investigations; D. M. U. C. Dissanayake, R. A. S. D. Rathnasekara, and K. A. M. Kularathne were responsible for formal analysis and methodology; M. D. N. R. Dayananada and W. S. M. Botheju prepared the original draft and further edited the manuscript; Janitha A. Liyanage was responsible for funding acquisition, resources, and supervision; S. K. Weragoda was responsible for resources and supervision in instrumentation.

\section{Acknowledgments}

This research was funded by the research project PS/DSP/ CKDU/06/3.5 titled "Establish a CKDu Information and Research Center at University of Kelaniya, Sri Lanka." The authors would like to acknowledge the National Institute of Fundamental Studies (NIFS), Kandy, Sri Lanka. They would like to thank Amila T. Kannangara, Amitha Suriyaarachchi, Erandi Udayasiri, and Sudesh Hemal for supporting sample collection and analysis.

\section{References}

[1] E. S. Wijewickrama, N. Gunawardena, S. Jayasinghe, and C. Herath, "CKD of unknown etiology $(\mathrm{CKDu})$ in Sri Lanka: a multilevel clinical case definition for surveillance and epidemiological studies," Kidney International Reports, vol. 4, no. 6, p. 781, 2019.

[2] S. Rajapakse, M. C. Shivanthan, and M. Selvarajah, "Chronic kidney disease of unknown etiology in Sri Lanka," International Journal of Occupational and Environmental Health, vol. 22, no. 3, p. 259, 2016.

[3] M. a. C. S. Jayasumana, P. a. Paranagama, M. D. Amarasinghe et al., "Possible link of chronic arsenic toxicity with chronic kidney disease of unknown etiology in Sri Lanka," Journal of Natural Sciences Research, vol. 3, no. 1, 2013.

[4] R. Chandrajith, S. Nanayakkara, K. Itai et al., "Chronic kidney diseases of uncertain etiology (CKDue) in Sri Lanka: geographic distribution and environmental implications," Environmental Geochemistry and Health, vol. 33, no. 3, p. 267, 2010.

[5] S. H. Jadhav, S. N. Sarkar, R. D. Patil, and H. C. Tripathi, "Effects of subchronic exposure via drinking water to a mixture of eight water-contaminating metals: a biochemical and histopathological study in male rats," Archives of Environmental Contamination and Toxicology, vol. 53, no. 4, pp. 667-677, 2007.

[6] R. Reza and G. Singh, "Heavy metal contamination and its indexing approach for river water," International Journal of 
Environmental Science \& Technology, vol. 7, no. 4, pp. 785792, 2010.

[7] S. Nanayakkara, T. Komiya, N. Ratnatunga et al., "Tubulointerstitial damage as the major pathological lesion in endemic chronic kidney disease among farmers in north central province of Sri Lanka," Environmental Health and Preventive Medicine, vol. 17, no. 3, pp. 213-221, 2012.

[8] R. A. Wuana and F. E. Okieimen, "Heavy metals in contaminated soils: a review of sources, chemistry, risks and best available strategies for remediation," International Scholarly Research Notices, vol. 2011, Article ID 402647, 20 pages, 2011.

[9] N. I. Agalakova and G. P. Gusev, "Molecular mechanisms of cytotoxicity and apoptosis induced by inorganic fluoride," ISRN Cell Biology, vol. 2012, Article ID 403835, 16 pages, 2012.

[10] O. Abollino and M. Aceto, "Heavy metals in agricultural soils from Piedmont, Italy. Distribution, speciation and chemometric data treatment," Chemosphere, vol. 49, p. 545557, 2002.

[11] S. J. Cobbina, Y. Chen, Z. Zhou et al., "Toxicity assessment due to sub-chronic exposure to individual and mixtures of four toxic heavy metals," Journal of Hazardous Materials, vol. 294, pp. 109-120, 2015.

[12] M. H. Whittaker, G. Wang, X.-Q. Chen et al., "Exposure to Pb, $\mathrm{Cd}$, and as mixtures potentiates the production of oxidative stress precursors: 30-day, 90-day, and 180-day drinking water studies in rats," Toxicology and Applied Pharmacology, vol. 254, no. 2, p. 154, 2011.

[13] B. P. Panigrahy, P. K. Singh, A. K. Tiwari, B. Kumar, and A. Kumar, "Assessment of heavy metal pollution index for groundwater around Jharia coalfield region, India," Journal of Biodiversity and Environmental Sciences, vol. 6, no. 3, pp. 33-39, 2015.

[14] E. Gimeno-García, V. Andreu, and R. Boluda, "Heavy metals incidence in the application of inorganic fertilizers and pesticides to rice farming soils," Environmental Pollution, vol. 92, no. 1, pp. 19-25, 1996.

[15] S. V. Mohan, P. Nithila, and S. J. Reddy, "Estimation of heavy metals in drinking water and development of heavy metal pollution index," Journal of Environmental Science and Health. Part A: Environmental Science and Engineering and Toxicology, vol. 31, no. 2, pp. 283-289, 1996.

[16] G. Muller, "Index of geoaccumulation in sediments of the rhine river," Geojournal, vol. 2, no. 3, pp. 108-118, 1969.

[17] E. L. Ander, C. C. Johnson, M. R. Cave, B. Palumbo-Roe, C. P. Nathanail, and R. M. Lark, "Methodology for the determination of normal background concentrations of contaminants in English soil," Science of the Total Environment, vol. 454-455, pp. 604-618, 2013.

[18] C. Peter Keller, "Geographic information systems for geoscientists: modeling with GIS," Computers \& Geosciences, vol. 21, no. 9, pp. 1-50, 1996.

[19] I. Babiker and M. A. A. Mohamed, "Assessment of groundwater contamination by nitrate leaching from intensive vegetable cultivation using geographical information system," Environment International, vol. 29, no. 8, pp. 1009-1017, 2004.

[20] M. Gupta and P. K. Srivastava, "Integrating GIS and remote sensing for identification of groundwater potential zones in the hilly terrain of Pavagarh, Gujarat, India," Water International, vol. 35, no. 2, pp. 233-245, 2010.

[21] S. Singh, N. C. Ghosh, G. Krishan, R. Galkate, T. Thomas, and R. K. Jaiswal, "Development of an overall water quality index (OWQI) for surface water in Indian context," Current World Environment, vol. 10, no. 3, pp. 813-822, 2015.
[22] M. Dashtizadeh, H. Kamani, S. D. Ashrafi et al., "Human health risk assessment of trace elements in drinking tap water in Zahedan city, Iran," Journal of Environmental Health Science and Engineering, vol. 17, no. 2, pp. 1163-1169, 2019.

[23] SLS-614, Sri Lankan Drinking Water (Portable Water) Quality Standards, https://www.slsi.lk/im ages/downloads/other/ accredited_tests_1.pdf, 2013.

[24] R. W. Dharmaratne, "Fluoride in drinking water and diet: the causative factor of chronic kidney diseases in the north central province of Sri Lanka," Environmental Health and Preventive Medicine, vol. 20, no. 4, pp. 237-242, 2015.

[25] S. J. Reddy, "Encyclopaedia of Environmental Pollution and Control", Environmental Media, Environmental Media, vol. 1, p. 342, Karlia, India, 1995.

[26] S. Sauvé, W. Hendershot, and H. E. Allen, "Solid-solution partitioning of metals in contaminated soils: dependence on $\mathrm{pH}$, total metal burden, and organic matter," Environmental Science \& Technology, vol. 34, no. 7, pp. 1125-1131, 2000.

[27] A. Facchinelli, L. Sacchi, and E. Mallen, "Multivariate statistical and GIS-based approach to identify heavy metal sources in soils," Environmental Pollution, vol. 114, pp. 313-324, 2000.

[28] P. A. Kabata and H. Pendias, Trace Elements in Soil and Plants, CRC Press, Boca Raton, FL, USA, 2000.

[29] S. Khan, Q. Cao, Y. M. Zheng, Y. Z. Huang, and Y. G. Zhu, "Health risks of heavy metals in contaminated soils and food crops irrigated with wastewater in Beijing, China," Environmental Pollution, vol. 152, no. 3, pp. 686-692, 2008.

[30] A. J. P. Navarro, A. I. Aguilar, and M. J. R. López, “Aspectos bioquímicos y genéticos de la tolerancia y acumulación de metales pesados en plantas," Ecosistemas, vol. 16, pp. 10-25, 2007.

[31] S. V. Adams, P. A. Newcomb, M. M. Shafer et al., "Sources of cadmium exposure among healthy premenopausal women," Science of the Total Environment, vol. 409, no. 9, pp. 16321637, 2011.

[32] B. Lokeshappa, K. Shivpuri, V. Tripathi, and K. A. Dikshit, "Assessment of toxic metals in agricultural produce," Food Public Health, vol. 2, pp. 24-29, 2012.

[33] S. G. Rueda, V. J. A. Rodríguez, and M. R. Madriñán, "Metodologías para establecer valores de referencia de metales pesados en suelos agrícolas perspectivas para Colombia," Acta Agronómica, vol. 60, pp. 203-217, 2011.

[34] S. Rostami, H. Kamani, S. Shahsavani, and M. Hoseini, "Environmental monitoring and ecological risk assessment of heavy metals in farmland soils," Human and Ecological Risk Assessment: An International Journal, pp. 1-13. In press.

[35] G. S. Valladares, O. A. d. Camargo, J. R. P. d. Carvalho, and A. M. C. Silva, "Assessment of heavy metals in soils of a vineyard region with the use of principal component analysis," Scientia Agricola, vol. 66, no. 3, pp. 361-367, 2009.

[36] G. J. M. Trujillo and M. M. A. Torres, "Niveles de contaminación en tres sectores de villavicencio, a través del índice de geo-acumulación (I-geo)," Orinoquia, vol. 19, no. 1, p. 109, 2015.

[37] H. Ranasinghe, "Organic agriculture as a sustainable solution to chronic kidney disease unidentified (CKDu)," International Journal of Multidisciplinary Studies, vol. 3, no. 2, pp. 71-77, 2016.

[38] R. T. Perera, N. Dayananda, S. Botheju et al., "Heavy metal contamination in surface sediments of major tanks in Anuradhapura district; A CKDu endemic district in Sri Lanka," International Journal of Environmental Quality, vol. 41, pp. 40-48, 2021. 